\title{
Leukocytoclastic Vasculitis with Systemic Involvement Associated with Ciprofloxacin Therapy: Case Report and Review of the Literature
}

\author{
Bruno Morgado ${ }^{1}$, Catarina Madeira ${ }^{2}$, Joana Pinto ${ }^{1}$, Joana Pestana ${ }^{2}$ \\ 1. Department of Biomedical Sciences and Medicine, University of Algarve 2. Department of Internal \\ Medicine, Hospital Centre of Algarve
}

$\square$ Corresponding author: Bruno Morgado, brunolcmorgado@gmail.com Disclosures can be found in Additional Information at the end of the article

\section{Abstract}

A 71-year-old woman presented with constitutional signs and lower extremity palpable purpura after being prescribed a four-day course of $500 \mathrm{mg}$ of ciprofloxacin two times daily for a gastrointestinal infection. She was admitted for inpatient treatment. During the third hospital day, she presented with an episode of abundant hematemesis while her skin lesions remained unchanged. Upper endoscopy revealed multiple lesions consistent with vasculitis and histological examination of the skin biopsy disclosed a leukocytoclastic vasculitis. The patient was successfully treated with prednisone following ciprofloxacin discontinuation. Complete resolution of the lesions on drug withdrawal strongly suggested drug toxicity, which was further supported by a score of 8 in the Naranjo Adverse Drug Reaction Probability Scale. Awareness that the development of skin and gastrointestinal lesions following administration of ciprofloxacin may be a manifestation of ciprofloxacin-induced vasculitis can help early detection, treatment, and lead to an overall good prognosis.

Categories: Internal Medicine, Allergy/Immunology, Rheumatology

Keywords: ciprofloxacin, vasculitis

\section{Introduction And Background}

Ciprofloxacin is a generally safe and extensively used drug in everyday clinical practice only rarely associated with hypersensitivity reactions. These reactions are largely characterized by pruritus, rash, or photosensitivity and occur in less than $2 \%$ of users [1].

Received 11/05/2016

Review began 11/14/2016

Review ended 11/20/2016

Published 11/28/2016

C Copyright 2016

Morgado et al. This is an open access article distributed under the terms of the Creative Commons Attribution License CC-BY 3.0., which permits unrestricted use, distribution, and reproduction in any medium, provided the original author and source are credited.
We described a case of an elderly woman with several comorbidities that developed leukocytoclastic vasculitis (LCV) with cutaneous and gastrointestinal involvement after a fourday course of ciprofloxacin for the treatment of a gastrointestinal infection. The authors consider relevant to report this case because, although ciprofloxacin-related cutaneous vasculitis is rare, the diagnosis can be challenging as the clinical picture may be indistinguishable from other forms of vasculitis. The diagnosis requires a high degree of suspicion, particularly due to a possibly fatal outcome. It is important for clinicians to be alerted to this potential adverse effect that can be easily treated with drug discontinuation. Additionally, the case presents gastrointestinal involvement, which had been unreported to date, and was successfully treated with drug withdrawal and glucocorticoid therapy.

\section{How to cite this article}

Morgado B, Madeira C, Pinto J, et al. (November 28, 2016) Leukocytoclastic Vasculitis with Systemic Involvement Associated with Ciprofloxacin Therapy: Case Report and Review of the Literature. Cureus 8(11): e900. DOI 10.7759/cureus.900 


\section{Cureus}

\section{Review}

\section{Case report}

A 71-year-old overweight woman with no personal or family history of dermatologic conditions, atopy, or adverse drug reactions presented to her primary care facility with a 12hour history of abundant watery diarrhea, together with colic-type abdominal pain, vomiting, and negative for stool blood, pus, or mucus. Her history was positive for essential hypertension. She was observed by her primary care provider and was prescribed ciprofloxacin and an oral saline rehydration formula after which she was discharged. Four days later, she presented to our emergency department with no symptomatic improvement and complained of new onset arthralgias, myalgias, fatigue, and lower limb skin lesions described as small, reddish, slightly pruriginous macules. Her medications included telmisartan, $40 \mathrm{mg}$ daily, hydrochlorothiazide, $12.5 \mathrm{mg}$ daily, and the recently prescribed ciprofloxacin, $500 \mathrm{mg}$ two times daily. She referred to taking paracetamol, $1 \mathrm{~g}$ once to twice a week, for an occasional headache and denied use of any other over-the-counter or herbal medications. Physical examination was remarkable for signs of dehydration, a tympanic temperature of $38.3^{\circ} \mathrm{C}$, blood pressure of $107 / 54 \mathrm{mmHg}$, pulse of $87 / \mathrm{min}$, respiratory rate of $19 / \mathrm{min}$, and pulse oximetry of $98 \%$ on ambient air. Abdominal examination revealed only a slightly tender abdomen on palpation. Neurologic examination was normal. The skin presented with small, multiple violaceous discolorations of various sizes, ranging from approximately 1 to $6 \mathrm{~mm}$, visible over the medial and anterior aspect of the lower part of both lower limbs (Figure $1 A-1 D$ ). Informed patient consent was obtained at the time of treatment.
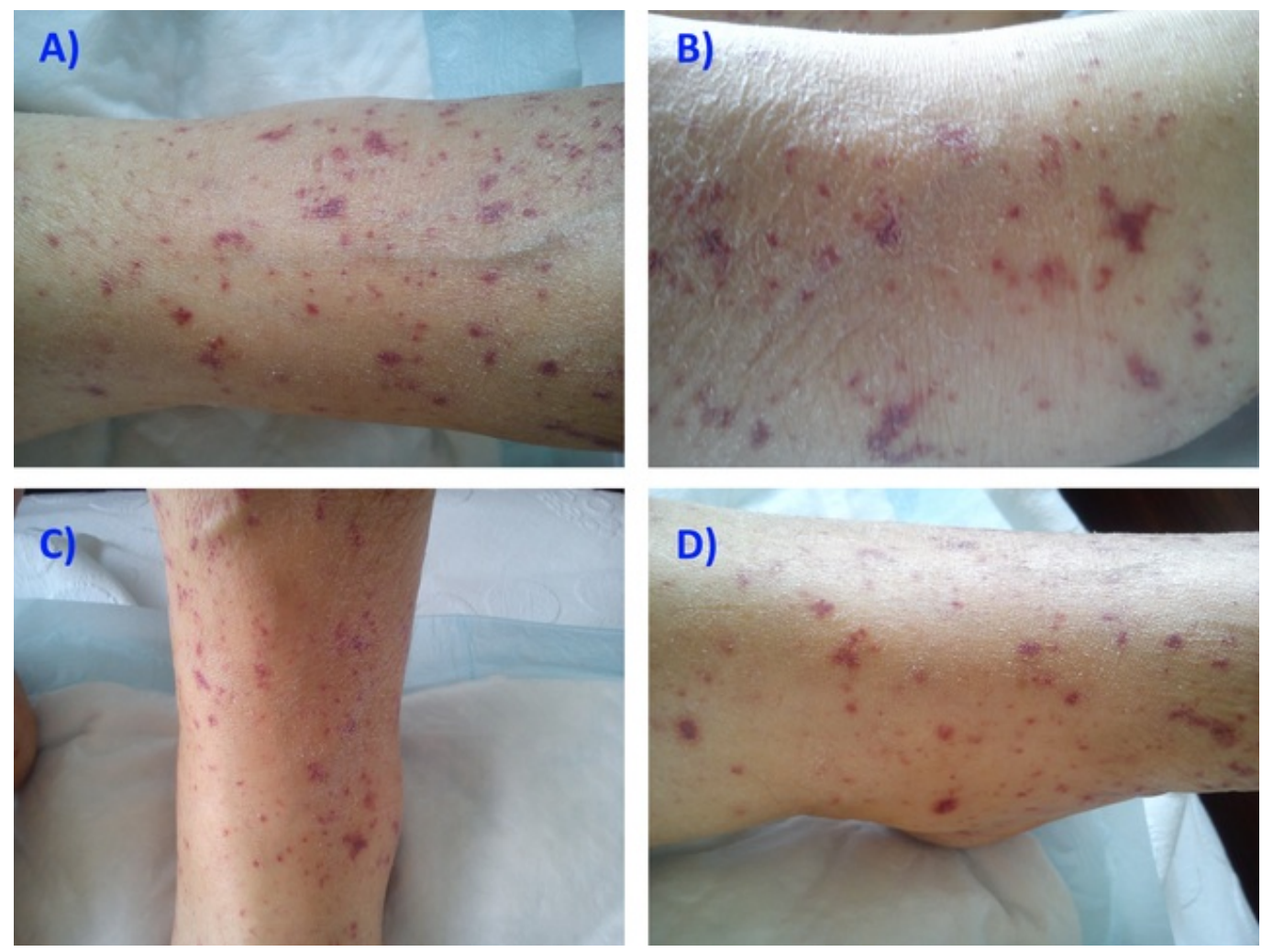

\section{FIGURE 1: Macroscopic view of the main lesions on admission}

The lesions cover the anterior and medial aspect of the lower limbs. They are violaceous discolorations of heterogeneous asymmetric shapes, sharp borders, and of various sizes ranging from 1 to $6 \mathrm{~mm}$. 
The lesions were non-blanching, tender, and slightly raised on palpation. Femoral and distal pulses were present, and there was no palpable femoral or inguinal lymphadenopathy as well as any further dermatological findings. Laboratory analysis disclosed a slight leukocytosis (12.3 $\mathrm{x}$ 10 9/L) and a C-reactive protein elevation (63 mg/L), hyperkalaemia $(5.65 \mathrm{mmol} / \mathrm{L})$, hypernatremia $(156 \mathrm{mmol} / \mathrm{L})$, elevated blood urea $(30 \mathrm{mg} / \mathrm{dL})$, and serum creatinine $(1.2$ $\mathrm{mg} / \mathrm{dL}$ ). She was admitted on the pretext of dehydration with inability to tolerate oral food or fluid intake, and the following acute problems were considered:

- Acute gastroenteritis of probable viral aetiology

- Renal impairment of mixed, but mainly pre-renal aetiology

- Electrolytic abnormalities

- Violaceous lesions on lower limbs of unknown aetiology

Oral and intravenous rehydration were undertaken as needed, and ciprofloxacin was not discontinued as other causes for the presented clinical findings were still being considered.

The day after admission, a skin punch biopsy was performed. In the search for evidence of systemic disease, further investigations were conducted that revealed no abnormalities in sedimentation rate, serum complement proteins C3 and C4, immunoglobulin A (IgA), angiotensin-converting enzyme (ACE), and circulating immunocomplexes. Anti-nuclear antibodies, antineutrophil cytoplasmic antibody (ANCA), anti-histone antibodies, rheumatoid factor, and anti-streptolysin-O were also negative. Serology for hepatitis B and C, as well as HIV, was negative. There was no indication of eosinophilia. After intravenous rehydration therapy, renal function and serum electrolytes improved and returned to baseline over the following days.

During the third hospital day, the pruritic lesions showed no signs of improvement and the patient presented with the sudden onset of hematemesis. Upper endoscopy revealed the presence of violaceous lesions of variable sizes over the gastric fundus and duodenal bulb, similar to the presenting skin lesions, and consistent with vasculitis (Figure $2 A-2 B$ ). 


\section{Cureus}

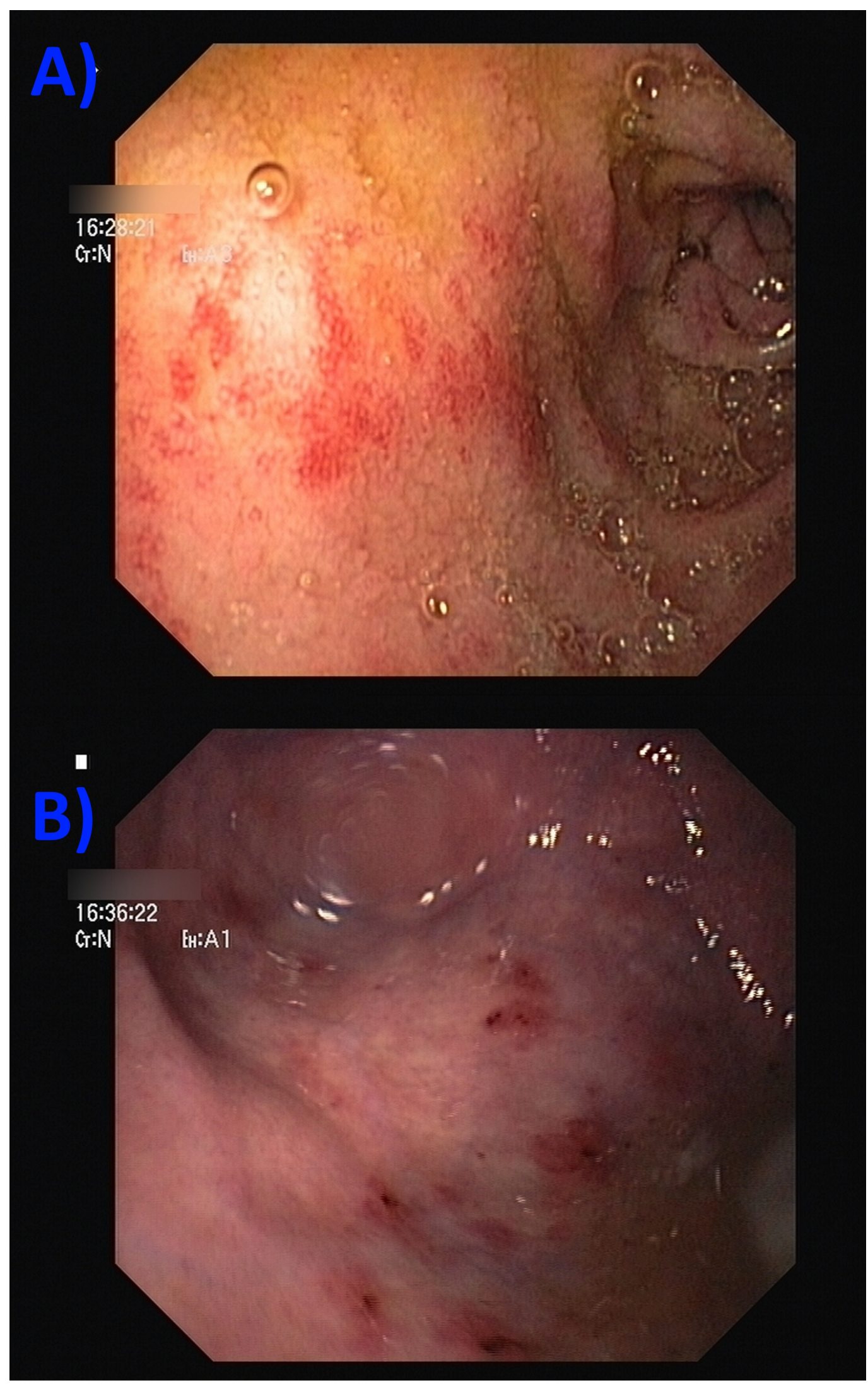

FIGURE 2: Endoscopic appearance of the gastric lumen

Lesions are observable over the (A) duodenal bulb and (B) gastric fundus, both consistent with vasculitis. 
Biopsies were not performed so as to avoid inducing further blood loss. Upper endoscopy also revealed what seemed to have been a significant amount of blood originating from the airway. Lower endoscopy was also performed and revealed no significant findings. Given the upper endoscopic findings of blood originating from the airway, plain chest X-ray and high-resolution computer tomography (CT) were ordered for the suspected respiratory system involvement and revealed no discernible abnormalities. The patient refused bronchoscopy examination.

Urinalysis and blood culture results were normal, and the rest of the physical examination showed no evidence of vasculitis involving other organ systems. At this time, the suspicion arose of systemic vasculitis associated with ciprofloxacin. This was followed by the immediate discontinuation of the drug. She was given a course of prednisone at a dose of $0.5 \mathrm{mg} / \mathrm{kg}$ daily with gradual improvement of the skin lesions over the following week and no new episodes of hematemesis. Biopsy of the skin lesions showed areas of LCV with a fragmentation of neutrophils and red blood cell extravasation. Other areas displayed features of oedema of the vessel wall and inflammatory infiltration with fibrinoid necrosis (Figure 3A-3B). 


\section{Cureus}
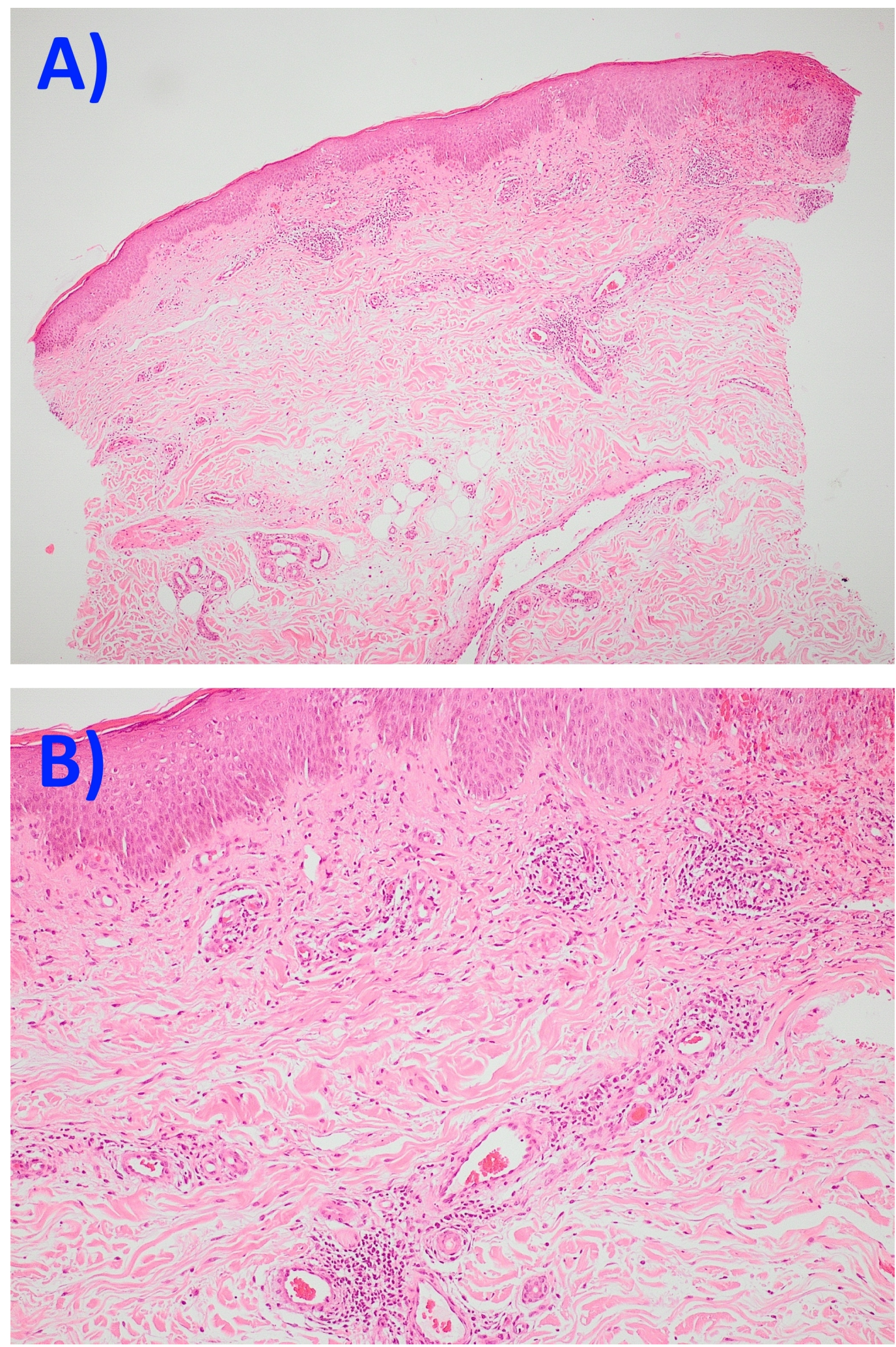

\section{FIGURE 3: Microscopic view of the skin lesions}

Leukocytoclastic vasculitis with fragmented neutrophils, red blood cell extravasation, and mild fibrinoid necrosis of the vascular wall. 


\section{Cureus}

were performed. We decided to further validate the diagnosis by resorting to the Naranjo Adverse Drug Reaction (ADR) Probability Scale, commonly used in clinical practice to determine the likelihood of whether an adverse drug reaction is due to a suspected drug or other causes (Table 1) [2].

\begin{tabular}{|c|c|c|c|c|c|}
\hline So & & Yes & No & $\begin{array}{l}\text { Do not } \\
\text { know }\end{array}$ & $\begin{array}{l}\text { Score in } \\
\text { this case }\end{array}$ \\
\hline 1 & Are there previous conclusive reports on this reaction? & +1 & 0 & 0 & +1 \\
\hline 2 & Did the adverse event occur after the suspected drug was administered? & +2 & -1 & 0 & +2 \\
\hline 3 & $\begin{array}{l}\text { Did the adverse reaction improve when the drug was discontinued or a specific } \\
\text { antagonist was administered? }\end{array}$ & +1 & 0 & 0 & +1 \\
\hline 4 & Did the adverse reaction reappear when the drug was re-administered? & +2 & -1 & 0 & 0 \\
\hline 5 & $\begin{array}{l}\text { Are there alternative causes (other than the drug) that could have, on their } \\
\text { own, caused the reaction? }\end{array}$ & -1 & +2 & 0 & +2 \\
\hline 6 & Did the reaction reappear when a placebo was given? & -1 & +1 & 0 & 0 \\
\hline 7 & $\begin{array}{l}\text { Was the drug detected in the blood (or other fluids) in concentrations known to } \\
\text { be toxic? }\end{array}$ & +1 & 0 & 0 & 0 \\
\hline 8 & $\begin{array}{l}\text { Was the reaction more severe when the dose was increased or less severe } \\
\text { when the dose was decreased? }\end{array}$ & +1 & 0 & 0 & +1 \\
\hline 9 & $\begin{array}{l}\text { Did the patient have a similar reaction to the same or similar drugs in any } \\
\text { previous exposure? }\end{array}$ & +1 & 0 & 0 & 0 \\
\hline \multirow[t]{2}{*}{10} & Was the adverse event confirmed by any objective evidence? & +1 & 0 & 0 & +1 \\
\hline & & & & Total & 8 \\
\hline
\end{tabular}

\section{TABLE 1: Naranjo Adverse Drug Reaction (ADR) Probability Scale}

Scoring $\geq 9$ = definite ADR; 5 - 8 = probable ADR; 1 - 4 = possible ADR; 0 = doubtful ADR.

In our case, the probability of a drug-induced LCV adverse reaction is scored as "probable" (score 8 , with a higher than 8 required for a definitive diagnosis). Given the severity of the previous clinical picture, we did not consider the possibility of reexposing the patient to the drug, a key point in many algorithms for a definitive diagnosis but seldom performed in clinical practice. Thus, by excluding other causes of systemic and gastrointestinal disease, we concluded that the most probable diagnostic hypothesis in the present case was a ciprofloxacin-induced cutaneous vasculitis with gastric involvement.

\section{Outcome and follow-up}

The patient made a good clinical recovery with complete resolution of diarrhoea and restoration of normal renal function. Upon discontinuation of the ciprofloxacin, the violaceous lesions displayed significant progress; within 48 hours, most lesions showed signs of 
improvement. There was complete resolution of the skin and gastrointestinal lesions on the upper endoscopy at 11 days after admission. The patient was discharged without symptoms and with almost complete resolution of the skin findings 12 days following admission. The adverse drug reaction was recorded as a known condition in the patient's medical record, and assistant physicians were notified of the present hypersensitivity and the possibility of cross-reaction with other agents in the same drug class. At follow-up consultations two, six, and 12 months after discharge, she remained clinically well with all observations within the normal range.

\section{Discussion}

Following evaluation of the patient's clinical history, laboratory and physical examination findings, a drug-induced cutaneous vasculitis was suspected with ciprofloxacin as the culprit. The time between first exposure to the drug and the onset of the first clinical findings range from three days to five weeks. This reaction appears to be reported in first-time users of the drug as well as with patients who took ciprofloxacin beforehand with no history of druginduced vasculitis [3-12].

LCV is an uncommon but potentially serious side effect of ciprofloxacin. It is a small-vessel vasculitis characterized histologically by leukocytoclasis and presenting cardinal features, such as palpable, violaceous papules, affecting most commonly the lower part of the legs. Other manifestations, such as fever, arthralgias, lymphadenopathy, and an elevated erythrocyte sedimentation rate, are present in most patients [13-14]. The exact mechanism of LCV remains unknown but is thought to be the result of a type III hypersensitivity reaction with deposition of immune complexes and consequent damage to blood vessels by neutrophils [15]. Schmid, et al. mentioned that quinolones can cause hypersensitivity reactions through several different pathophysiological mechanisms [16]. The clarification of such mechanisms may change our understanding of how to prevent this reaction in some patients.

There is a paucity of reports in the literature regarding cutaneous LCV with or without systemic involvement association with ciprofloxacin therapy. From 1989 to date, we found only 13 case reports of LCV related to ciprofloxacin use (Table 2) [3-12]. 


\section{Cureus}

\begin{tabular}{|c|c|c|c|c|c|c|c|}
\hline Dose & $\begin{array}{l}\text { Time to } \\
\text { clinical } \\
\text { onset }\end{array}$ & $\begin{array}{l}\text { Other } \\
\text { medications }\end{array}$ & $\begin{array}{l}\text { Diagnostic } \\
\text { method }\end{array}$ & $\begin{array}{l}\text { Affected } \\
\text { organ- } \\
\text { systems }\end{array}$ & $\begin{array}{l}\text { Final } \\
\text { diagnosis }\end{array}$ & Treatment & $\begin{array}{l}\text { Year } \\
\text { published }\end{array}$ \\
\hline $\begin{array}{l}500 \mathrm{mg} \\
\text { po BID }\end{array}$ & 3 days & None & Skin biopsy & Cutaneous & $\begin{array}{l}\text { Mononuclear- } \\
\text { cell infiltrate }\end{array}$ & $\begin{array}{l}\text { Removal of } \\
\text { ciprofloxacin }\end{array}$ & $1989^{[4]}$ \\
\hline $\begin{array}{l}500 \mathrm{mg} \\
\text { po QD }\end{array}$ & 4 days & Cephradine & Skin biopsy & Cutaneous & LCV & $\begin{array}{l}\text { Removal of } \\
\text { ciprofloxacin }\end{array}$ & $1992^{[11]}$ \\
\hline Unknown & 10 days & Diuretic & Clinical & Cutaneous & $\begin{array}{l}\text { Haemorrhagic } \\
\text { vasculitis }\end{array}$ & None & $1992^{[11]}$ \\
\hline Unknown & 4 days & Unknown & Skin biopsy & Cutaneous & $\begin{array}{l}\text { Mononuclear- } \\
\text { cell infiltrate }\end{array}$ & $\begin{array}{l}\text { Removal of } \\
\text { ciprofloxacin }\end{array}$ & $1994^{[8]}$ \\
\hline $\begin{array}{l}500 \mathrm{mg} \\
\text { po BID }\end{array}$ & 4 days & Fluoxetine & Clinical & Cutaneous & $\begin{array}{l}\text { Cutaneous } \\
\text { vasculitis }\end{array}$ & $\begin{array}{l}\text { Removal of } \\
\text { ciprofloxacin }\end{array}$ & $1997^{[6]}$ \\
\hline 375 mg & Unknown & Ceftriaxone & $\begin{array}{l}\text { Skin biopsy } \\
\text { and } \\
\text { rechallenge } \\
\text { test }\end{array}$ & Cutaneous & LCV & $\begin{array}{l}\text { Removal of drug } \\
\text { and negative } \\
\text { ceftriaxone } \\
\text { challenge test }\end{array}$ & $1997^{[5]}$ \\
\hline Unknown & Unknown & $\begin{array}{l}\text { Oral } \\
\text { antidiabetic, } \\
\text { nifedipine and } \\
\text { digoxin }\end{array}$ & $\begin{array}{l}\text { Clinical and } \\
\text { skin biopsy }\end{array}$ & $\begin{array}{l}\text { Cutaneous } \\
\text { and renal } \\
\text { vasculitis }\end{array}$ & LCV & $\begin{array}{l}\text { Removal of drug } \\
\text { and prednisone } \\
\text { treatment }\end{array}$ & $2001^{[7]}$ \\
\hline Unknown & 3 days & Several drugs & Skin biopsy & Cutaneous & LCV & $\begin{array}{l}\text { Removal of } \\
\text { ciprofloxacin }\end{array}$ & $2004^{[12]}$ \\
\hline Unknown & 10 days & None & $\begin{array}{l}\text { Clinical and } \\
\text { biopsy }\end{array}$ & $\begin{array}{l}\text { Cutaneous } \\
\text { and renal } \\
\text { vasculitis }\end{array}$ & $\begin{array}{l}\text { Cutaneous and } \\
\text { renal vasculitis }\end{array}$ & $\begin{array}{l}\text { Removal of drug } \\
\text { and prednisone } \\
\text { treatment }\end{array}$ & $2007^{[9]}$ \\
\hline Unknown & 7 days & Rifampin & Clinical & Cutaneous & $\begin{array}{l}\text { Drug-induced } \\
\text { vasculitis }\end{array}$ & $\begin{array}{l}\text { Removal of } \\
\text { ciprofloxacin }\end{array}$ & $2009^{[3]}$ \\
\hline Unknown & 10 days & Flucloxacillin & Clinical & Cutaneous & $\begin{array}{l}\text { Drug } \\
\text { hypersensitivity }\end{array}$ & $\begin{array}{l}\text { Removal of } \\
\text { ciprofloxacin }\end{array}$ & $2009^{[3]}$ \\
\hline $\begin{array}{l}500 \mathrm{mg} \\
\text { po BID }\end{array}$ & 4 days & Clindamycin & Clinical & Cutaneous & $\begin{array}{l}\text { Haemorrhagic } \\
\text { vasculitis }\end{array}$ & $\begin{array}{l}\text { Removal of } \\
\text { ciprofloxacin }\end{array}$ & $2010^{[10]}$ \\
\hline $\begin{array}{l}400 \text { mg } \\
\text { IV BID }\end{array}$ & 6 days & Clindamycin & Clinical & Cutaneous & $\begin{array}{l}\text { Haemorrhagic } \\
\text { vasculitis }\end{array}$ & $\begin{array}{l}\text { Removal of } \\
\text { ciprofloxacin }\end{array}$ & $2010^{[10]}$ \\
\hline
\end{tabular}

\section{TABLE 2: Prior Case Reports of Ciprofloxacin-induced Vasculitis}

LCV: leukocytoclastic vasculitis 
They described patients with a variety of clinical presentations, mostly presenting cutaneous LCV and constitutional signs, and a few provided confirmation of additional organ system damage. Of these, two cases reported LCV with renal involvement and only Storsley, et al. confirmed renal vasculitis with biopsy [7,9]. To the extent of our knowledge, the literature does not mention any case of ciprofloxacin-related vasculitis with gastrointestinal involvement [312]. Even though renal vasculitis with ciprofloxacin-induced LCV is rare, and gastrointestinal involvement has not been documented, drug-induced LCV is known to involve several systems, including the lungs and gastrointestinal tract [17-21]. Pace, et al. described systemic vasculitis with cutaneous, gastric, and renal involvement with the use of ofloxacin, another quinolone [22]. Likewise, Ceyhan, et al. reported an ofloxacin-induced vasculitis affecting the stomach and colon that presented clinically with bloody diarrhoea [23]. This is consistent with our patient presenting with hematemesis and endoscopic findings consistent with vasculitis following seven days of treatment. Not performing a gastric biopsy prevents us from making an accurate diagnosis of gastric involvement in our patient. Nevertheless, based on the clinical evidence of hematemesis, skin biopsy, and upper endoscopic findings before and after drug removal, we are confident that the gastric and duodenal mucosa presented with histologically similar lesions to the ones found on the skin, all attributable to treatment with ciprofloxacin.

Every patient believed to suffer from cutaneous vasculitis should undergo a detailed history, physical, and laboratory assessment. Diagnosing cutaneous vasculitis requires determination of the calibre of the vessels involved. Punch biopsy should be the method of choice since, as mentioned, LCV affects small vessels and the nature of the inflammatory infiltrate (neutrophilic, lymphocytic, or granulomatous) is one of the main factors considered for diagnosis. Since the composition of the infiltrate changes rapidly, an early biopsy is best if a reliable diagnosis is to be made [24]. Establishing the relationship between the offending agent and LCV is accomplished clinically and by the evident relationship between drug exposure and clinical presentation [25]. Some laboratory findings, such as ANCA and anti-histone antibodies, are occasionally helpful in the diagnosis of drug-induced vasculitis [9].

Cross-reactivity for the development of maculopapular exanthema with one fluoroquinolone predicts a recurrence with another fluoroquinolone for a small percentage of patients. Ball, et al. predicted a $10.4 \%$ probability of rash recurrence when taking ciprofloxacin in women who previously developed an exanthema with gemifloxacin. In the same study, several female patients who initially tolerated ciprofloxacin developed a rash when the treatment was again repeated with the same drug [26]. Even though cross-reactivity between ciprofloxacin and other quinolones have been described with the development of delayed-onset maculopapular cutaneous eruptions, to our knowledge, only one case has suggested an LCV resultant from cross-reactivity between quinolones. Blyth, et al. reported an LCV related with levofloxacin in a patient previously exposed to ciprofloxacin, raising the possibility of cross-reactivity reactions between quinolones, which can extend to full-blown LCV [24].

Owing to the rare nature of the phenomenon, no specific directives exist in managing ciprofloxacin-induced systemic LCV. Martinez-Taboada, et al. stated that discontinuation of the offending agent usually leads to resolution of the signs and symptoms in drug-induced LCV within days to weeks without the need of additional treatment. Some patients with joint symptoms may require non-steroidal anti-inflammatory drugs. Patients with a chronic or systemic disease may benefit from prednisone therapy. A minority of patients has been reported to require the addition of immunosuppressive agents, such as azathioprine or cyclophosphamide, to prednisone [27]. Most patients with this condition have a benevolent course following drug withdrawal, which should usually allow physicians to avoid overtreating these patients. Nevertheless, Pace, et al. described a case of fatal vasculitis associated with ofloxacin, and several reports have been made for drug-induced vasculitis with poor outcomes $[18,22]$. In view of the knowledge currently available, and considering the age, comorbidities, and systemic involvement which was particular to our patient, pre-emptive glucocorticoid 
therapy was deemed appropriate for 10 days. This proved to be adequate and consistent with other cases, as treatment duration for all patients in the reported cases ranged from four to 10 days [3-12].

Even though the safety profile of quinolones is similar to other classes of antibacterial agents, severe low-frequency adverse drug hypersensitivity reactions, which may include vasculitis, have occurred with a small number of specific quinolones, namely, ciprofloxacin, ofloxacin, and levofloxacin [24]. Ciprofloxacin is overall a well-tolerated and widely used drug that has been available for more than 25 years for the treatment of a multitude of bacterial infections [1]. The most common adverse effects reported involve the gastrointestinal tract, with less than $8 \%$ of patients experiencing side effects, such as nausea, vomiting, and diarrhoea. Central nervous system involvement is less common, with less than $6.4 \%$ of users enduring effects, such as headaches and dizziness. Only as few as $3.6 \%$ of patients go on to experience phototoxicity and hypersensitivity reactions in which vasculitis is included [28].

\section{Conclusions}

Consistent with preceding case reports linking the use of ciprofloxacin to LCV, we consider the former drug as the probable cause of LCV in our patient. Our patient presented with systemic vasculitis that included cutaneous and gastrointestinal involvement, which is unreported to date. Review of the current literature suggests the possibility of a cross-reaction between quinolones in causing LCV. As with previous case reports, our patient made a full recovery with prednisone treatment and removal of ciprofloxacin. While this condition is generally benign, it is important to recognize drug-induced LCV as it can be fatal without timely drug withdrawal.

\section{Additional Information}

\section{Disclosures}

Conflicts of interest: In compliance with the ICMJE uniform disclosure form, all authors declare the following: Payment/services info: All authors have declared that no financial support was received from any organization for the submitted work. Financial relationships: All authors have declared that they have no financial relationships at present or within the previous three years with any organizations that might have an interest in the submitted work. Other relationships: All authors have declared that there are no other relationships or activities that could appear to have influenced the submitted work.

\section{References}

1. Ball P, Tillotson G: Tolerability of fluoroquinolone antibiotics. Past, present and future . Drug Saf. 1995, 13:343-58. 10.2165/00002018-199513060-00004

2. Naranjo CA, Busto U, Sellers EM, Sandor P, Ruiz I, Roberts EA, Janecek E, Domecq C, Greenblatt DJ: A method for estimating the probability of adverse drug reactions . Clin Pharmacol Ther. 1981, 30:239-45. 10.1038/clpt.1981.154

3. Maunz G, Conzett T, Zimmerli W: Cutaneous vasculitis associated with fluoroquinolones. Infection. 2009, 37:466-68. 10.1007/s15010-009-8437-4

4. Choe U, Rothschild BM, Laitman L: Ciprofloxacin-induced vasculitis. N Engl J Med. 1989, 320:257-58. 10.1056/NEJM198901263200423

5. Reaño M, Vives R, Rodríguez J, Daroca P, Canto G, Fernández J: Ciprofloxacin-induced vasculitis. Allergy. 1997, 52:599-600. 10.1111/j.1398-9995.1997.tb02612.x

6. Lieu PK, Tok SC, Ismail NH, Chng HH: Ciprofloxacin-induced cutaneous vasculitis. Allergy. 1997, 52:593-94. 10.1111/j.1398-9995.1997.tb02607.x

7. Pons R, Escutia B: Ciprofloxacin-induced vasculitis with cutaneous and renal involvement (Article in Spanish). Nefrologia. 2001, 21:209-12.

8. Beuselinck B, Devuyst O: Ciprofloxacin-induced hypersensitivity vasculitis. Acta Clin Belg. 1994, 49:173-76. 10.1080/17843286.1994.11718384 
9. Storsley L, Geldenhuys L: Ciprofloxacin-induced ANCA-negative cutaneous and renal vasculitis--resolution with drug withdrawal. Nephrol Dial Transplant. 2007, 22:660-61. 10.1093/ndt/gfl554

10. van den Berg FP, Wagenvoort JH, van der Kleij AM, Teijink JA: Ciprofloxacin-induced hemorrhagic vasculitis. Ann Vasc Surg. 2010, 24:256.e13-256.e15. 10.1016/j.avsg.2009.05.015

11. Stubbings J, Sheehan-Dare R, Walton S: Cutaneous vasculitis due to ciprofloxacin. BMJ. 1992, 305:29. 10.1136/bmj.305.6844.29-b

12. Doménech JR, Afonso J, Gómez-Pavón J, Betancor E, Isach M: Vasculitis leucocitoclástica secundaria a ciprofloxacino (Article in Spanish). Revista Española de Geriatría y Gerontología. 2004, 39:395-98. 10.1016/S0211-139X(04)74995-1

13. Sams WM Jr, Thorne EG, Small P, Mass MF, McIntosh RM, Stanford RE: Leukocytoclastic vasculitis. Arch Dermatol. 1976, 112:219-26. 10.1001/archderm.1976.01630260039011

14. Calabrese LH, Duna GF: Drug-induced vasculitis. Curr Opin Rheumatol. 1996, 8:34-40.

15. van Rossum AP, Pas HH, Fazzini F, Huitema MG, Limburg PC, Jonkman MF, Kallenberg CG: Abundance of the long pentraxin PTX3 at sites of leukocytoclastic lesions in patients with small-vessel vasculitis. Arthritis Rheum. 2006, 54:986-91. 10.1002/art.21669

16. Schmid DA, Campi P, Pichler WJ: Hypersensitivity reactions to quinolones. Curr Pharm Des. 2006, 12:3313-26. 10.2174/138161206778194033

17. Jennette JC, Falk RJ: Small-vessel vasculitis. N Engl J Med. 1997, 337:1512-23. 10.1056/NEJM199711203372106

18. Doyle MK, Cuellar ML: Drug-induced vasculitis. Expert Opin Drug Saf. 2003, 2:401-409. 10.1517/14740338.2.4.401

19. Yamauchi K, Sata M, Machiya J, Osaka D, Wada T, Abe S, Otake K, Kubota I: Antineutrophil cytoplasmic antibody positive alveolar haemorrhage during propylthiouracil therapy for hyperthyroidism. Respirology. 2003, 8:532-35. 10.1046/j.1440-1843.2003.00499.x

20. Lee JY, Chung JH, Lee YJ, Park SS, Kim SY, Koo HK, Lee JH, Lee CT, Yoon HI: Propylthiouracil-induced nonspecific interstitial pneumonia. Chest. 2011, 139:687-90. 10.1378/chest.10-1558

21. Klemmer PJ, Chalermskulrat W, Reif MS, Hogan SL, Henke DC, Falk RJ: Plasmapheresis therapy for diffuse alveolar hemorrhage in patients with small-vessel vasculitis. Am J Kidney Dis. 2003, 42:1149-53. 10.1053/j.ajkd.2003.08.015

22. Pace JL, Gatt P: Fatal vasculitis associated with ofloxacin. BMJ. 1989, 299:658. 10.1136/bmj.299.6700.658

23. Ceyhan BB, Lawrence R, Sungur M, Ahiskali R, Celikel T: Ofloxacin-induced vasculitis. Intern Med. 1995, 34:872-74. 10.2169/internalmedicine.34.872

24. Blyth DM, Markelz E, Okulicz JF: Cutaneous leukocytoclastic vasculitis associated with levofloxacin therapy. Infect Dis Rep. 2012, 4:e11. 10.4081/idr.2012.e11

25. Grau RG: Drug-induced vasculitis: New insights and a changing lineup of suspects . Curr Rheumatol Rep. 2015, 17:71. 10.1007/s11926-015-0545-9

26. Ball P, Mandell L, Patou G, Dankner W, Tillotson G: A new respiratory fluoroquinolone, oral gemifloxacin: a safety profile in context. Int J Antimicrob Agents. 2004, 23:421-29. 10.1016/j.ijantimicag.2004.02.014

27. Martinez-Taboada VM, Blanco R, Garcia-Fuentes M, Rodriguez-Valverde V: Clinical features and outcome of 95 patients with hypersensitivity vasculitis. Am J Med. 1997, 102:186-91. 10.1016/S0002-9343(96)00405-6

28. Stahlmann R, Lode H: Safety considerations of fluoroquinolones in the elderly: an update . Drugs Aging. 2010, 27:193-209. 10.2165/11531490-000000000-00000 